Historic, Archive Document

Do not assume content reflects current scientific knowledge, policies, or practices. 

The Home Beautiful

is made more attractive with

ROSES and Shrubbery

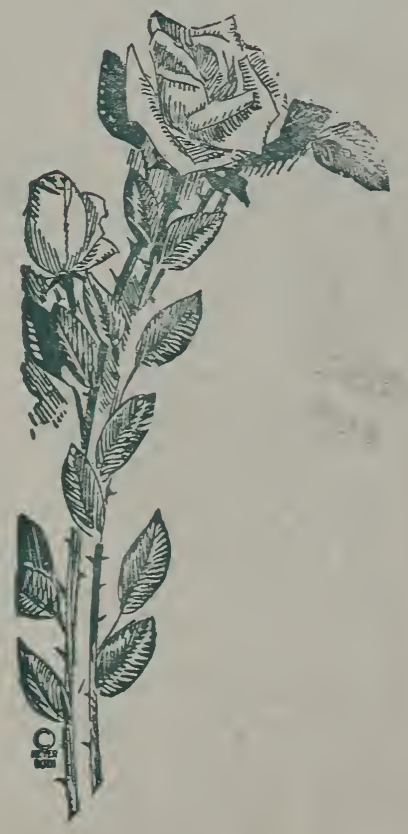

Texas Rose Garden

A. C. FRANKLYN

Rockdale, Texas Member

American Rose Society 
To Our Many Friends and Customers:

In presenting our catalogue for this season, we wish to thank our many friends and customers for their kind recommendations and to assure them that our best efforts will be used to merit their continued confidence.

\section{ROSES}

\section{A Few Facts About Our Roses}

Our roses are all field grown budded plants that have bloomed in the field this season. Twoyear plants are well branched, 18 to 30 inches high, according to variety, before cutting back to ship. One-year plants are about 12 inches. All plants are well rooted and matured. Plants are dug fresh for your order the day shipped; this insures you getting healthy plants that are full of life.

We offer only varieties that have proved good. Weak growers and poor bloomers have been discarded, these have been selected from hundreds of varieties.

A trial will convince you that our roses are the best you can buy anywhere at any price.

Our Nurseries are inspected each season by the State Inspector and are entirely free from all disease.

We take the greatest care in filling orders to see that all plants are true to name, up to grade and in perfect condition, and are ready to make good any errors we might make. We guarantee all plants to reach their destination in good condition, but when we have done this our responsibility ceases because we know if they receive proper treatment they will grow nicely. Many plants die from neglect and carelessness and in such cases we cannot and should not be expected to replace them.

Express charges are paid by us on all orders amounting to $\$ 5.00$ or more, smaller orders buyer pays charges.

Club Orders-Get your friends to order with you and for each four dozen roses ordered at $\$ 5.00$ per dozen you may select one dozen free of charge. When sending these club orders be sure to give the full address of each member of the club as we do this to get those who buy roses on our mailing list so that we can send them our catalogues as issued.

Shipping season opens November 1st, and closes April 1st. Fall and early winter is the best time to plant as early planting gives the plant time to make new roots before the growing season in the spring.

Pruning-We cut back all roses before shipping, but after you receive the plants, cut back 
any broken roots with a sharp knife and shape up the bushes, leaving only the strongest branches and cut these back to about six inches. Plant a little deeper, about one inch, than they were before. Be sure to firm the dirt around the plants and water well.

\section{ROSES}

Prices-Two year old plants 50 cents each, $\$ 5.00$ per dozen.

One year old plants 25 cents each, $\$ 3.00$ per dozen.

\section{BUSH ROSES}

Alexander Hill Gray-Deep lemon yellow similar in color to Marechal Neil, double flowers of perfect form, free flowering.

America, (Hill's America)-Large, rose-pink, fine shaped flowers, sweetly scented, carried on iong stems.

American Beauty-Rich, red, beautiful in form and color, very fragrant, large and double.

Angelus-Very double flowers of medium size, creamy white in color.

Antoine Revoire-Creamy white, delicately tinted with pink, extra large petals, making a bloom of beautiful form.

Raby Rambler-Small flowers of a brilliant red in large clusters, always in bloom. Fine for edging.

Bride-One of the best white roses for cut flowers, blooms of good size and very double, on good stiff stems, a very fine bloomer.

Bridesmaid-Just like the Bride, but of a clear shining pink, a fine double pink rose.

Charles K. Douglas-Strong growth, bloom flaming scarlet of medium size.

Columbia-Flowers of peach blow pink, of good size on long stems, a good cut flower rose.

Crimson Druschki-Dark red, large and double.

Commonwealth-Bud large, long, pointed; flower large, double and very lasting. Deep pink. Continuous bloomer.

Crusader-A strong growing variety; the growth is heavy and the flower stems strong. Free flowering; double; color a rich velvetcrimson.

Duchess of Iuxemburg-Deep orange yellow, large buds of good form.

Double White Killarney-Double the petals 
of the White Killarney, pure white in color and a good bioomer.

Etoile de France-Flowers are a beautiful shade of clear red, and of a velvety texture, one of the very finest of red roses.

Etoile de Holland-Bush strong, blooms darls velvety red of good size.

Etoile de Lyon-Deep golden yellow, very double and a good bloomer.

Edith Cavell-The brightest Polyantha brilliant scarlet with white eye.

F. K. Druschki-The White American Beauty, pure white flowers of extra large size and waxy texture.

Frank W. Dunlop-Color, shape and size much like Mrs. Russell, but a strong grower and good bloomer.

Francis Scott Key-Large very double flowers with high pointed center, fine for cutting and one of the best red roses.

General McArthur-Vivid Scarlet, the most ceautiful shade of any rose grown and one of the best growers and bloomers.

Golden Ophelia-Rich golden yellow, one of the best yellow roses for cutting.

Gorgeous-Flowers are large and full. Deep orange yellow and heavily veined with reddish copper.

Hadley-Deep velvety-crimson, retaining its color at all seasons.

Hoosier Beauty-Color glowing, deep crimson with darker shadings. Upright, strong, free good form.

Helen Gould-Long pointed buds, full double flowers, always in bloom, rosy crimson in color.

J. J. L. Mock-Imperial pink, flowers of good form on long stiff stems, one of our best pink roses.

K. A. Victoria-Pure white, large buds, and full double flowers, a strong grower and a constant bloomer. The best of all white roses for the garden.

Killarney-The Irish Beauty, long pointed 
buds of beautiful imperial pink. The buds last well after cutting.

Killarney Brilliant-The Red Killarney, like Killarney only in color, which is a beautiful crimson pink.

La France-An old favorite, silvery rose, petals of satiny texture. Flowers large and double.

Los Angeles-Flame pink, very fragrant, long pointed buds of the most beautiful form, not a good grower in some localities.

Lady Hillingdon-This is the best yellow rose for cut flowers we grow, long pointed buds of richest golden yellow on long stiff stems.

Maman Cochet-Rich rosy pink, beautiful in bud and flower, very double and always in bloom.

Mme. Caroline Testout-Or Giant La France, brilliant satiny rose in color, flowers of immense size. A very strong growing rose.

Mme. Butterfly-Bright pink suffused with apricot and gold, this is the "Glorified Ophelia."

My Maryland-Salmon pink of a soft and pleasing shade, long pointed buds on good stems for cutting, very fragrant.

Mrs. Aaron Ward-A most striking shade of indian yellow, shading to lemon at edges of petals, splendid garden and cut rose.

Nims. Edouard Herriot-Deep terra-cotta or reddish-copper. Free blooming. The "Daily Mail" Rose.

Mrs. Charles Bell-A new Radiance, same form and good qualities as Radiance, flowers are of a shell pink, also known as the shell Pink Radiance.

Mrs. H. R. Darlington-Color creamy-yellow; fragrant and very free. Perfect in form; a good grower.

Mrs. Segond Weber-Large flowers of sof $t$ salmon pink perfectly formed.

Mrs. George Shawyer-Brilliant rose pink, good size and grower.

National Emblem-Dark crimson buds like a red Sunburst.

Natalie Bottner-Large, full, perfectly formed 
flowers of creamy yellow, strong growing upright bushes and a good bloomer.

Ophelia-Brilliant salmon flesh shaded with rose pink and orange, a profuse bloomer and considered the best rose of its color.

Paul Neyron-The largest of all roses, bright shining pink, clear and beautiful, very double and almost thornless.

Pilgrim-Silvery pink, large perfectly formed flowers of good substance for cutting.

Rose Premier-The handsomest dark pink rose to date, beautiful buds and very double flowers, a constant bloomer.

Rhea Reid-Deep red, large and double, very fragrant, a good bloomer and a strong grower.

Radiance-Brilliant rosy pink, beautiful buds and flowers on very stiff stems, a very strong grower and a constant bloomer, considered by many the best pink rose of ali.

Red Radiance-Identical with the Pink Radiance except in color which is a bright clear shade of red, both are extra fine cut flower roses.

Rev. F. Page Roberis-Orange yellow buds, good open flowers. A fine garden rose.

Souv. de Claudius Pernet-Sunflower yellow, large buds and double flowers.

Sensation-Dark crimson, a good bloomer and strong grower. A fine cut flower.

Sunburst-Golden orange in color, with immense long buds on good stems for cutting, an extra good yellow rose.

Soliel d' Or-Flowers large, fragrant and very double, color varying from orange yellow to ruddy gold shaded with Nasturtium red, a strong grower and a constant bloomer.

Templar-Bright velevty crimson, strong grower.

White Cochet-Very large and double, beautiful in bud and flower, pure white with a rink flush, vigorous and a constant bloomer.

White Killarney-Pure waxy white, long pointed buds, a fine cut rose. 
White Malmason-Pure white, sweetly scented, and very double, flowers opening out flat.

White American Beauty-See F. K. Druschki which is the same.

White Ophelia-Pure white sport. Growth somewhat stronger than Pink Ophelia.

\section{CLIMBING ROSES}

\section{Prices Same as Bush Roses}

\section{Cover That Fence or Trellis With Climbing Roses}

Climbing American Beauty-A very strong climber, flowers of medium size in clusters, a beautiful shade of red.

Cl. Columbia-Identical in bloom with the bush, a very strong climber.

Cl. Caroline Testout-By far the best pink climber, flowers very large and of the same bright shade of pink as the bush Testout.

Climbing Etoile de France-Dark red flowers of good size, a good bloomer.

Climbing K. A. Victoria-Mrs. Robert Peary, Ivory white flowers of good size and double, a good white climber.

Climbing Killarney-Flowers and foliage the same as the Killarney, but a strong climber.

C1. Lady Hillingdon---Just like the bush in flower but a good climber.

Nary Wallace-Blooming with great freedom in Spring and bearing a considerable number of fine budis in summer and fall. Flowers large, well formed, semi-double, of a bright clear rosepink.

Climbing Meteor-This is the darkest red climber of all, flowers freely and very strong.

Marechal Neil-The Queen of all the yellow roses, deep golden yellow, a profuse bloomer and very fragrant.

Cl. Radiance-One of the best pink climbing roses, blooms like the bush.

Cl. Sunburst-Like the bush in flower, but a very strong climber. 
R. M. Henrietta-Buds and flowers of brilliant red, a strong and good bloomer. The best red we grow.

Climbing White Cochet-A very strong climber with the same beautiful buds and double flowers as the bush.

Climbing Wooten-Velvety red flowers in great profusion, almost thornless and a good grower.

\section{SPRING BLOOMING CLIMBERS}

\section{Price-25 cents each, $\$ 3.00$ per dozen}

This class of roses bloom only in the early spring, but they bloom in such profusion then that they pay for the time they are idle. They are the strongest climbing roses we have and will cover a fence or trellis in a very little time.

Dr. Van Fleet-A delicate shade of flesh pink flowers in large clusters, double and very fragrant.

Dorothy Perkins-Very large clusters of flowers, very double and fragrant, a beautiful shade of shell pink.

Escelsa-The Red Dorothy, same habit as above, but of an intense crimson.

Paul's Scarlet Climber-The most brilliant rose known, vivid scarlet, large semi-double flowers in clusters of from five to eight.

Rosarie-An even shade of deep pink, plant almost thornless.

Silver Moon-Clear shining white, with a mass of yellow stamens, petals large and beautifully cupped.

Thousanc Beauties-Florers of different shades from delicate flesh to deep pink, almost thornless.

White Dorothy-Same as Dorothy Perkins, but pure white in color.

White Banksia-A tender thornless climber, flowers very double and with a violet fragrance.

Yellow Banksia-Same as above, but with yellow flowers 


\section{Evergreens}

All Evergreens are two years old, from 10 to 30 inches in height according to character of plant. Price 50 cents each, except where noted. Write for prices of larger plants.

Abelia Grandiflora-One of the prettiest of shrubs, with glossy green and brown foliage; bears countless, small, fragrant flowers of light rose color all through summer. $18 \mathrm{in.}$

Arborvitae, Compact-Close compact growth, golden green in color. 8 inch.

Arborvitae, Pyramidal-A tall, slender type, very much used now. 10 inch.

Boxwood-A highly ornamental plant of dwarfish habit, with small, glossy, dark green leaves. Fine for formal planting and low hedges. 35 cents; 8 inches.

Cape Jasmine-Dark glossy foliage, pure white flowers in May and June. 12 inches.

Cypress (Italian Cypress)-A tall growing, slender tree with erect branches, the whole making a pillar of green. Graceful and stately. Our stock is of true, narrow type. 75 cents. 24 in.

C. Arizonica (Arizona Cypress)-A remarkabiy attractive, narrow pyramidal type of cypress with bluish-green foliage. Native of mountains of Arizona. Suitable to hot and dry sections of interior, but equally at home in this climate. 12 inches.

Euonymous Radicans-A low growing variety with small veined leaves. 25 cents; 10 inches.

Euonymous Compacta-A very compact dwarf variety, easily shaped to any desired form. 8 inch. 25 cents.

Euonymous R. Variagated-Same as ałove but leaves green and white. 25 cents; 6 inches.

Euonymous Japonica-A handsome evergreen, compact and erect. Leares glossy dark green throughout the year. Very useful either as single specimen, in mass, or as ledge. It can be trimmed into different forms, 18 inches.

Holly-A tall growing tree, with short, spreading branches forming a shapely pyramidal head; leaves dark shining green; bears berries of beautiful scarlet. 12 inches, 75 cents. 
Ligustrum Japonica-One of the most attractive, vigorous and easily growing variety of Privets, with very broad, glossy green foliage, effective in almost any planting scheme. 20 inches; price 35 cents.

Magnolia Grandiflora-The grandest broadleaved evergreen of the Southern forest, famous for its large white, fragrant blooms and beautiful, broad, glossy leaves. Price 75 cents; 30 in. 12 in., 50 cents.

Myrtie or Sweet Myrtic-A dwarf shrub with small, bright green leaves, as aromatic as Bay. Flowers pure white and fragrant. 12 inches.

Nandina-A beautiful shrub from Japan, with numerous upright, reed-like stems springing from same root. Leaves rich red when young, dark green at maturity, assuming coppery nue in winter. Produces clusters of red berries in autumn. 10 inches.

Gleander (Nerium)-Well known ever-green flowering shrub of the South, hardly requiring description. We hare them in single red, single white, at 25 cents each, 30 inches.

Photenia Dentata-An attractive evergreen shrub, compact and upright, with large, finelytooth, glossy green leaves, which partially assume very conspicuous reddish tint in fall. Produces white flowers early in the spring. 12 inches.

Pittosporum-The popular variety originally brought from Japan. Leaves of lustrous green, rather oral in shape, forming a dense, giobular head, which can be pruned into many different shapes. 10 inches.

Wax Leaf Ligustrum-Glossy dark green leathery foliage, large painicles of sweetly scented. flowers in spring. 18 inches.

Wild Peach or Carolina Cherry Laurel-A valuable native evergreen. Tall growing, symmetrical and very bushy. Leaves of medium size, bright green, finely-toothed around the edge; flowers white and pleasantly fragrant, followed by abundance of shining, black berries. 21 inches. 


\title{
Hedge Plants
}

Amur River Privet-The best hedge privet for the south; uniform growth of its branches and foliage, its adaptability to be trimmed into any form, make this an ideal variety for that purpose, Price 2-3 ft., 10 cents each.

Callifornia, Privet-Too well known to need description. Price 18-24 inches, 8 cents.

Lodense Privet-Very dwarf and compact, growing only about 15 inches. Price 10 cents.

\section{Ornamental Flowering Shrubs}

\author{
Price-25 cents each; $\$ 3.00$ per dozen \\ Except Where Noted
}

Very useful to use as screens, hedges or as single specimens. Some bloom early in spring before we have any other flowers, some in the hot dry summer when most other flowers are gone.

Althea-Colors, red, white, pink and purple, large double rose shaped flowers in summer and fall.

Bridalwreath-Single or double, graseful arching branches covered with round clusters of white flowers in eariy spring.

Bush Honeysuckle-Pink and white, fragrant flowers in spring, red berries in fall. This makes a good hedge.

Crape IIyrtle-Colors red, white and pink; lrage panicles of fringed flowers all summer. very attractive.

Deutzia-Well known erect shrub, producing an abundance of double-petaled, rose-tinted white blooms in spring and early summer.

Flowering Willow-A real dry weather shrub or small tree; it does best in mid-summer and then is a mass of bloom. Colors are white and purple.

Flowering Pomegranite-Dark, glossy foliage, bright red Fuchsia-like flowers in the summer. 
Japan Flowering Quince or Burning BushA thorny bush with fiery red flowers, often in mid-winter.

Lilac-The old purple flowering Lilac; no home is complete without it.

Mallow Marvels-Hardy Hibiscus, mixed colors white, pink and red; very large flowers all summer.

Pearl Bush-Pearl white flowers in spring. Price 50 cents.

Pussy Willow-Silky catkins in spring.

Red Bud-Red pea-shaped flowers in the early spring.

Spirea Anthony Waterer-Grows about 15 inches high, blooms all season, rosy red flowers. Price 35 cents.

Spirea Billardi-Pink and white; flowers in plume like spikes all summer.

Syringa or Mock Orange-Pure white flowers with pretty yellow stamens; blooms in May and June.

Tamarix-Plumosa-Light green feathery foliage, pink flowers in summer.

Vitex or Lavender Shrub-Long spikes of purple flowers in mid-summer, one of our best summer shrubs.

Weigela-A free flowering, vigorous shrub producing large and showy rose-colored flowers covering its spreading branches. Price 50 cents.

\section{Grasses}

Pampas Grass-Large clumps. 25 cents.

Pennisetum Grass-A dwarf plume grass. Large clumps. Price 25 cents.

Any of the above grasses $\$ 1.50$ per dozen for good divisions. 


\section{Vines}

Price 25 cents each

Every home has a place for a few vines. They are fine for shade on porches, to cover trellises and to run on unsightly houses.

Evergreen Honeysuckle-The well known white flowering kind, will cover a large space in a very short time.

Coral Honeysuckle-Tubular coral red flowers all summer, one of the best vines for porches as it does not grow too dense.

Wisteria-A very strong growing vine, with long drooping clusters of pea shaped purple flowers.

Trumpet Vine-This vine will cling to wood or any surface without support, large red trumpet shaped flowers all summer.

Queen's Crown-A strong growing dainty vine covered with pink flowers from July until frost.

\section{Shades}

Chinese Elm-The best and fastest growing shade tree. 3-4 feet, 35 cents. $\$ 4.00$ per dozen. 4-5 feet 50c, $\$ 5.00$ per dozen.

\section{Bulbs}

Mexican Tuberose-50 cents per dozen.

Angel Lily -15 cents each.

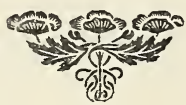


MADE IN

$\pi^{*} \star^{*} t^{*} x^{*} \star^{*}$ ROCKDALE IIIIIII U.S.A. BY THE ROCKDALE REPORTER

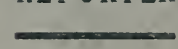

